\title{
ВІДДАЛЕНI РЕЗУЛЬТАТИ ХІРУРГІЧНОЇ КОРЕКЦІЇ НЕДОСТАТНОСТІ МІТРАЛЬНОГО КЛАПАНА ВНАСЛІДОК ПОРУШЕННЯ ЦІЛІСНОСТІ ХОРААЛЬНО-ПАПІЛЯРНОГО АПАРАТУ
}

\section{О. О. Большак, В. І. Мнішенко, О. М. Трембовецька, В. М. Бешляга, І. В. Леошко, В. В. Попов Національний інститут серцево-судинної хірургії імені М. М. Амосова НАМН України, м. Київ \\ REMOTE RESULTS OF SURICAL CORRECTION OF THE MITRAL VALVE INSUFFICIENCY DUE TO DISORDER OF THE CHORDO-PAPILLARY APPARATUS INTEGRITY}

\section{O. O. Bohlshak, V. I. Mnishenko, O. M. Trembovetska, V. M. Beshlyaga, I. V. Leoshko, V. V. Popov}

Amosov National Institute of Cardio-Vascular Surgery, Kyiv

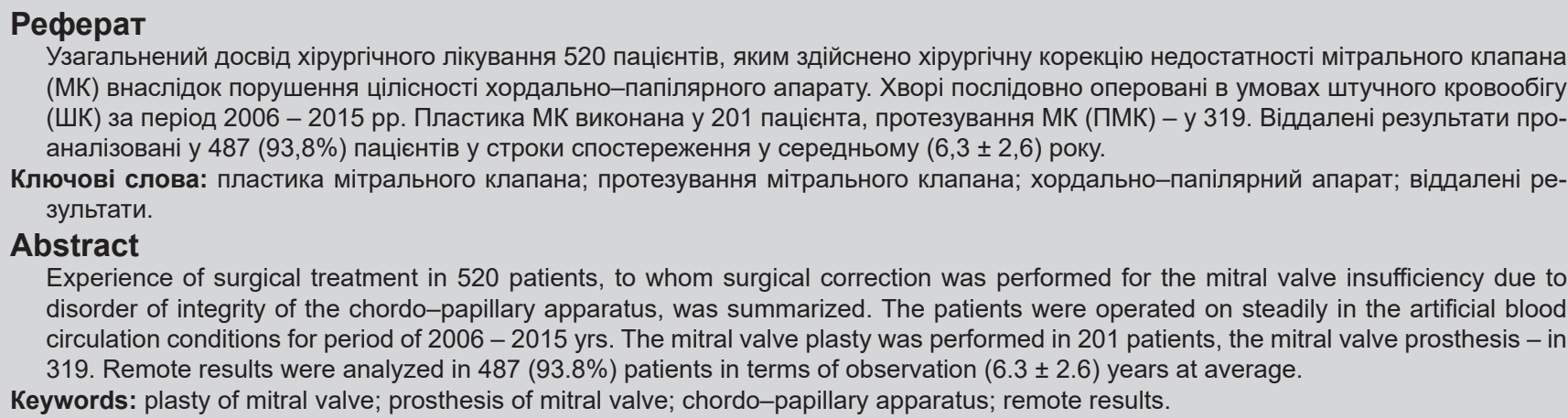

Ключові слова: пластика мітрального клапана; протезування мітрального клапана; хордально-папілярний апарат; віддалені результати.

Abstract

Experience of surgical treatment in 520 patients, to whom surgical correction was performed for the mitral valve insufficiency due to disorder of integrity of the chordo-papillary apparatus, was summarized. The patients were operated on steadily in the artificial blood circulation conditions for period of $2006-2015 \mathrm{yrs}$. The mitral valve plasty was performed in 201 patients, the mitral valve prosthesis - in 319. Remote results were analyzed in $487(93.8 \%)$ patients in terms of observation $(6.3 \pm 2.6)$ years at average.

Keywords: plasty of mitral valve; prosthesis of mitral valve; chordo-papillary apparatus; remote results.

Недостатність МК внаслідок порушення цілісності хордально-папілярного апарату відзначають у 9 - 17\% спостережень всіх вад МК та у 32 - 41\% - в структурі недостатності МК [1 - 3]. Хордально-папілярний апарат МК, що перебуває в абсолютному анатомічному взаємозв'язку, утворюе своєрідний замкнений силовий контур лівого шлуночка (ЛШ) серця: волокнисте кільце - стулки - сухожильні струни - соскоподібні м'язи - міокард ЛШ - волокнисте кільце. Порушення його цілісності спричиняе порушення замикальної функції стулок МК, що зумовлює мітральну регургітацію $[1,4$ - 6]. За «чистої» або переважаючої недостатності МК порушення гемодинаміки зумовлені зворотнім струмом крові через уражений МК під час систоли шлуночків. Величина регургітації визначається різницею тиску між передсердям і шлуночком, а також площею зони незмикання стулок МК. Об'ємне перевантаження лівого передсердя (ЛП) зумовлює об'ємне перевантаження ЛШ і далі - його дилатацію та гіпертрофію. За повно- го спорожнення ЛП в діастолу і поштовхоподібного надходження в нього крові середній тиск у передсерді підвищується меншою мірою, ніж за стенозу МК, отже, рефлекс Кітаєва включається пізніше і виражений значно менше, ніж при стенозі МК. Підвищення тиску в ЛП і застій в малому колі кровообігу зумовлені збільшенням залишкового об'єму крові в ньому. У міру прогресування легеневої гіпертензії збільшується правошлуночкова недостатність і недостатність кровообігу у великому колі $[1,3,5,7-9]$.

В останні роки кардіохірурги приділяють все більше уваги пластичним методикам корекції недостатності МК з порушенням цілісності хордально-папілярного апарату. Перевагами пластичних втручань $€$ спрощення антикоагулянтної терапіі, менша частота тромбоемболічних ускладнень після операції. В той же час, пластична корекція є більш складною процедурою, ніж протезування, потребує досвіду хірурга, більшої тривалості перетискання аорти та ШК, інтраопераційного ехокарді- ографічного контролю [1 - 3].

Отже, проблема вибору найбільш ефективного методу хірургічного лікування недостатності МК актуальна.

Мета дослідження: аналіз віддалених результатів хірургічнї корекції недостатності МК з порушенням цілісності хордально-папілярного апарату з використанням різних методів.

\section{МАТЕРІАЛИ I МЕТОДИ ДОСЛІДЖЕННЯ}

За період 2006 - 2015 рр. в клініці послідовно оперовані 520 хворих 3 приводу недостатності МК внаслідок порушення цілісності хордально-папілярного апарату. У дослідження не включали пацієнтів, яким здійснене супутне протезування клапана аорти. Чоловіків було 367 (70,6\%), жінок - 153 (29,4\%). Вік хворих у середньому $(55,9 \pm 9,9)$ року. У 201 (38,7\%) пацієнта здійснено пластичну корекцію МК (група А), у 319 (61,3\%) - протезування МК (група Б). У 2 хворих після пластичного втручання виникла необхідність проте- 
зування МК на госпітальному етапі, тому вони включені до групи Б.

При аналізі віддалених результатів операцій застосовані анамнестичні, статистичні методи, ехокардіографія, електрокардіографія, ендоваскулярні методи, анкетування, листування, активний виклик пацієнтів по телефону тощо.

Основні характеристики пацієнтів представлені у табл. 1.

За статтю та віком хворі суттево не різнилися, проте, тривалість захворювання, наявність та тривалість фібриляції передсердь, IV функціональний клас (за NYHA) достовірно частіше спостерігали у пацієнтів групи Б, що свідчило про більш тяжкий стан до операції.

За даними ехокардіографії, кінцево-діастолічний об'єм ЛШ до операції становив у середньому у пацієнтів групи A - $(200,5 \pm 46,4)$ мл, групи Б - $(210,3 \pm 48,4)$ мл; кінцево-систолічний об'єм - відповідно (78,1 \pm $24,3)$ та $(88,6 \pm 26,8)$ мл; фракція викиду (ФВ) ЛШ - $(61,9 \pm 12,5)$ та $(58,9$ $\pm 14,0) \%$; систолічний тиск в легеневій артерії (СТЛА) - (52,2 $\pm 15,3)$ та $(53,1 \pm 15,1)$ мм рт. ст. $(\mathrm{p}>0,05)$. Отже, достовірної різниці показників ехокардіографії до операції не було, проте, дилатація лівих відділів серця у пацієнтів групи Б була дещо більшою, а скоротливість Лш - дещо меншою.

Крім корекції недостатності МК, у 136 (67,7\%) хворих групи А і 171 (53,6\%) групи Б виконували супутні хірургічні процедури ( $<0,05)$. Пластика ЛП та процедура MAZE виконана у 17 (5,3\%) пацієнтів групи Б; пластика тристулкового клапана (ТК), в т. ч. 3 пластикою ЛП та MAZE - у 104 (51,7\%) пацієнтів групи А та $82(25,7 \%)$ - групи Б (p < 0,05); коронарне шунтування (КШ) - у 8 (4,0\%) та 47 (14,7\%) (p < 0,05); пластика ТК з КШ - у $17(8,4 \%)$ та 20 (6,3\%) (p > $0,05)$; інші втручання - у 7 (3,5\%) та $5(1,6 \%)(\mathrm{p}<0,05)$. Тобто, у пацієнтів групи А частіше виконували пластику ТК (в основному - профілактичну, за невеликої та помірної регургітаціiі). Ішемічну хворобу серця, що потребувала КШ, навпаки, частіше виявляли у пацієнтів групи Б (відповідно у 21 і 12,4\%), що також свідчило про більшу тяжкість вихідного стану хворих цієї групи.

Інтраопераційно тривалість перетискання аорти у групах А і Б стано-

Таблиця 1. Загальна характеристика пацієнтів до операції

\begin{tabular}{|c|c|c|}
\hline \multirow{2}{*}{ Показник } & \multicolumn{2}{|c|}{ Величина показника в групах } \\
\hline & $A(n=201)$ & $5(n=319)$ \\
\hline Чоловіки, абс. (\%) & $144(71,6)$ & $223(69,9)$ \\
\hline Жінки, абс. (\%) & $57(28,4)$ & $96(30,1)$ \\
\hline Середній вік, років ( $\bar{x} \pm \mathrm{m})$ & $55,1 \pm 9,2$ & $56,5 \pm 10,1$ \\
\hline Тривалість захворювання, років ( $\bar{x} \pm \mathrm{m})$ & $5,7 \pm 2,8$ & $7,8 \pm 4,5^{*}$ \\
\hline Фібриляція передсердь, абс. (\%) & $40(19,9)$ & $91(28,5)^{*}$ \\
\hline Тривалість фібриляції передсердь, років $(\bar{x} \pm m)^{\Delta}$ & $4,3 \pm 0,9$ & $8,2 \pm 2,5^{*}$ \\
\hline \multicolumn{3}{|l|}{ Функціональний клас NYHA, абс. (\%) } \\
\hline II & $60(29,9)$ & $63(19,7)^{*}$ \\
\hline III & $102(50,7)$ & $150(47,0)$ \\
\hline IV & $39(19,4)$ & $106(33,2)^{*}$ \\
\hline \multicolumn{3}{|c|}{$\begin{array}{ll}\text { Примітка. } & { }^{\Delta} \text { - тривалість фібриляції передсердь до операції відома у } 17(42,5 \%) \\
& \text { пацієнтів групи А та } 48(52,7 \%) \text { групи Б; }{ }^{*} \text { - різниця показників вірогідна } \\
& \text { у порівнянні з такими в групі А }(p<0,05) . \text { Те ж у табл. } 2-3 .\end{array}$} \\
\hline
\end{tabular}

вила відповідно $(110,5 \pm 38,8)$ і $(87,1$ $\pm 22,5)$ хв $(\mathrm{p}<0,05)$, ШК - $(171,6 \pm$ $49,3)$ та $(136,8 \pm 31,7)$ хв $(\mathrm{p}<0,05)$; за супутньої пластики ТК тривалість перетискання аорти - (113,8 \pm $37,7)$ i $(95,7 \pm 27,2)$ хв $(\mathrm{p}<0,05)$, ШК $-(173,7 \pm 48,1)$ та $(150,3 \pm 39,4)$ хв (p $<0,05)$; за супутнього КШ тривалість перетискання аорти - $(102,8 \pm 29,8)$ та $(112,4 \pm 28,3)$ хв $(\mathrm{p}>0,05)$, ШК $(159,6 \pm 40,5)$ та $(176,7 \pm 47,1)$ хв $(\mathrm{p}<$ $0,05)$; за супутнього КШ та пластики ТК тривалість перетискання аорти $(141,8 \pm 38,4)$ та $(135,0 \pm 35,6)$ хв (р $>0,05)$, ШК - $(220,6 \pm 51,1)$ та $(200,9$ $\pm 46,3)$ хв ( $<$ 0,05). Тривалість перетискання аорти та ШК більша у групі А майже в усіх підгрупах, що свідчить про більшу складність методики порівняно з протезуванням.

Гістологічне дослідження МК проведено у 450 (86,5\%) хворих, в тому числі 157 (78,1\%) - групи А та 293 (91,8\%) - групи Б ( $<0,05)$, у 4 пацієнтів групи Б виконане протезування МК з повним збереженням підклапанного апарату. Фіброеластична недостатність МК (в т.ч. хвороба Барлоу) виявлена у 51 (32,5\%) пацієнта групи А та у 89 (30,4\%) - групи Б ( $>$ > 0,05); дисплазія стулок, хорд (в т.ч. малі вроджені аномаліі) - відповідно у 79 (50,3\%) та 152 (51,9\%) (p > 0,05); вікові зміни (фіброз, ліпоїдз, кальциноз) - у 21 (13,4\%) та 41 $(14,0 \%)(\mathrm{p}>0,05) ;$ ревмовальвуліт - у $6(3,8 \%)$ та 11 (3,7\%) (p > 0,05).

Таким чином, достовірної різниці щодо частоти етіології недостатності МК з порушенням цілісності хордально-папілярного апарату в групах не було. На госпітальному етапі помер один хворий групи Б (летальність в групі 0,3\%, загальна - 0,2\%).

\section{РЕЗУЛЬТАТИ}

У віддаленому періоді проаналізовані результати у 487 (93,8\%) пацієнтів, в тому числі - 192 (95,5\%) - групи А та 295 (92,8\%) - групи Б. Тривалість спостереження у середньому $(6,3 \pm 2,6)$ року.

Віддалені результати оцінювали як хороший, задовільний, незадовільний. Хорошим вважали результат при ПМК: за відсутності дисфункції протеза, СТЛА 30 мм рт. ст. і менше, наявність синусового ритму, ФВ Лш 55\% і більше, відсутність тромбоемболічних ускладнень і повторних втручань; при пластиці діастолічний градієнт на МК 5 мм рт. ст. і менше, СТЛА 30 мм рт. ст. і менше, наявність синусового ритму, ФВ ЛШ 55\% і більше, відсутність тромбоемболічних ускладнень і повторних втручань.

Задовільний результат при ПМК: наявність фібриляції передсердь, СТЛА 30 - 50 мм рт. ст., ФВ ЛШ 40 - 55\%, відсутність тромбоемболічних ускладнень і повторних операцій; при пластиці: діастолічний градієнт на МК 6 - 9 мм рт. ст., СТЛА 30 - 50 мм рт. ст., наявність фібриляції передсердь, ФВ ЛШ 40-55\%, відсутність тромбоемболічних ускладнень та повторних операцій.

Незадовільним результат при ПМК вважали: за наявності дисфункції протеза (діастолічний градієнт тиску понад 20 мм рт. ст., помірна та більш виражена параклапанна недостатність), ФВ ЛШ менше 40\%, здійснення чи необхідність виконання повторних операцій, наявність тромбоемболічних ускладнень, значної серцевої недостатності $(\mathrm{CH})$. Незадовільний результат при пластиці: діастолічний градієнт 
Таблиця 2. Віддалені результати протезування та пластики Мк

\begin{tabular}{|lcccccc|}
\hline \multirow{3}{*}{ Результат } & \multicolumn{6}{c|}{ Кількість спостережень в групах } \\
\cline { 2 - 7 } & \multicolumn{2}{c}{$\mathrm{A}(\mathrm{n}=192)$} & \multicolumn{2}{c|}{ Б $(\mathrm{n}=295)$} & \multicolumn{2}{c|}{ Разом $(\mathrm{n}=487)$} \\
\cline { 2 - 7 } & абс. & $\%$ & абс. & $\%$ & абс. & $\%$ \\
\hline Хороший & 45 & 24,0 & 73 & 24,7 & 118 & 24,2 \\
\hline Задовільний & 106 & 55,2 & 166 & 56,3 & 272 & 55,8 \\
\hline Незадовільний & 32 & 16,6 & 24 & 8,1 & 56 & 11,5 \\
\hline Померли & 9 & 4,7 & 32 & 10,8 & 41 & 8,4 \\
\hline
\end{tabular}

Таблиця 3. Причини смерті хворих

\begin{tabular}{|lcccc|}
\hline \multirow{2}{*}{\multicolumn{1}{c}{ Причина }} & \multicolumn{4}{c}{ Кількість спостережень в групах } \\
\cline { 2 - 5 } & \multicolumn{2}{c|}{ А (n=9) } & \multicolumn{2}{c|}{ Б (n=32) } \\
\cline { 2 - 5 } & абс. & $\%$ & абс. & $\%$ \\
\hline Тромбоемболічні ускладнення & - & - & 13 & 40,6 \\
\hline СН (в т.ч. гострий інфаркт міокарда) & 2 & 22,2 & 9 & 28,1 \\
\hline Інфекційні ускладнення (повторна операція) & 1 & 11,1 & 1 & 3,1 \\
\hline Раптова смерть & 3 & 33,3 & - & - \\
\hline Невідома & - & - & 5 & 15,6 \\
\hline Онкологічні захворювання & 2 & 22,2 & 3 & $9,4^{*}$ \\
\hline Інші & 1 & 11,1 & 1 & 3,1 \\
\hline
\end{tabular}

тиску 10 мм рт. ст. і більше, помірна та більш виражена регургітація на МК, ФВ ЛШ менше 40\%, наявність чи необхідність виконання повторної операції, наявність тромбоемболічних ускладнень, значної СН.

Частота хороших і задовільних віддалених результатів в обох групах була майже однаковою (табл. 2). Проте, в групі Б більша кількість хворих померли у віддаленому періоді, в групі А - більша частота незадовільних результатів. У 5 (2,6\%) хворих групи А у віддаленому періоді виконано повторну операцію (ПМК - у 4; пластику МК - в 1), у 4 з них - 3 приводу значної недостатності МК, в 1 інфекційного ендокардиту оперованого МК. У 5 (1,7\%) хворих групи Б виконано повторну операцію (у 4 ПМК, в 1 - пластику ТК), у 3 з них з приводу протезного інфекційного ендокардиту, в 1 - тромбозу протеза
МК, в 1 - значної недостатності ТК.

В групі А у віддаленому періоді не було летальних випадків внаслідок тромбоемболічних ускладнень.

Натомість, в групі Б у віддаленому періоді 3 хворих раптово померли на тлі загального задовільного стану, можливо, внаслідок аритміі. Летальність, пов'язана з СН та інфекційними ускладненнями, в обох групах була майже однаковою (табл. 3).

Після ПМК переважали незадовільні результати у віддаленому періоді внаслідок тромбоемболічних ускладнень, прогресуючої СН. В той же час, у пацієнтів після пластичного втручання значно частіше спостерігали порушення функції МК (підвищений градієнт, пов'язаний з формуванням помірного стенозу, помірна та більш виражена регургітація).

В групі А в 1 (0,5\%) хворого у віддаленому періоді виникло гостре пору- шення кровообігу головного мозку (ГПКГМ), що не спричинило летального наслідку. В групі Б тромбоемболічні ускладнення (ГПКГМ, тромбоз протеза) виникли у 24 (8,1\%) хворих, 13 зиих померли $(\mathrm{p}<0,05)$.

\section{ОБГОВОРЕННЯ}

Представлені віддалені результати виконаних оперативних втручань у 520 пацієнтів з приводу недостатності МК внаслідок порушення цілісності хордально-папілярного апарату 3 застосуванням різних методик за період 2006 - 2015 р. Вихідні показники в досліджуваних групах суттево не різнилися. В групі Б дещо частіше відзначали фібриляцію передсердь, супутню ішемічну хворобу серця, що потребувала КШ, що свідчило про більшу тяжкість стану пацієнтів цієї групи. Тривалість перетискання аорти та ШК була достовірно меншою при ПМК, ніж при пластиці, що може свідчити про меншу технічну складність ПМК порівняно з пластикою.

У віддалені строки проаналізовані результати у 93,8\% пацієнтів. Частота хороших та задовільних результатів в обох групах майже однакова (до 80\%), що свідчило про значну надійність обох методик корекції. Незадовільні результати у пацієнтів групи А були в основному зумовлені порушенням функції МК, в групі Б - тромбоемболічними ускладненнями, що пов'язане з труднощами контролю антикоагулянтної терапіі, прогресуванням $\mathrm{CH}$.

Причиною смерті хворих у віддаленому періоді після ПМК найчастіше були тромбоемболічні ускладнення та прогресуюча $\mathrm{CH}$, після пластичних втручань - прогресування СН та раптова смерть.

\section{REFERENCES}

1. Dzemeshkevich SL, Stivenson LU. Bolezni mitralnogo klapana. Moskva: Meditsina; 2000. 362 s. [In Russian].

2. David TE, Armstrong S, Ivanov J. Chordal replacement with polytetrafluoroethylene sutures for mitral valve repair: a 25-year experience. J Thorac Cardiovasc Surg. 2013;145:1563-9.

3. De Bonis M, Lapenna E, Taramasso M, et al. Is commissural closure associated with mitral annuloplasty a durable technique for the treatment of mitral regurgitation? A long-term ( $\leq 15$ years) clinical and echocardiographic study. Ibid. 2014;147:1900-6.

4. Sokolov VV. Implantatsiya protezov mitralnogo klapana s sokhraneniem podklapannykh struktur (disertatsiya). Moskva;1990. 172 s. [In Russian].

5. Alfieri O, Lapenna E. Systolic anterior motion after mitral valve repair: where do we stand in 2015? Eur J Cardiothorac Surg. 2015;48:3446. DOI: 10.1093/ejcts/ezv230. PMID: 26142473.
6. Chan V, Ahrari A, Ruel M, Elmistekawy E, Hynes M, Mesana TG. Perioperative deaths after mitral valve operations may be over estimated by contemporary risk models. Ann Thorac Surg. 2014;98:60510.

7. Dobrotin SS, Bogdanevich SV, Zemskova EP. Puti uluchsheniya rezultatov protezirovaniya mitralnogo klapana sokhraneniem zadney stvorki i podkapannykh struktur. Vestnik khirurgii im. Grekova. 2000;(3):12-5. [In Russian]

8. Prikhodko VP, Loganenko DI, Mikhaylov AV, Molchanov AN, Medvedev AP, SHirokov MV. Varianty khirurgicheskogo lecheniya posttravmaticheskikh porokov serdtsa. Patologiya krovoobrashcheniya i kardiokhirurgiya. 2005;(4):18-22. [In Russian].

9. Wang Z, Zhou C, Gu H, Zheng Z, Hu S. Mitral valve repair versus replacement in patients with rheumatic heart disease. J Heart Valve Dis. 2013;22:333-9. 